\title{
IMPLEMENTASI NILAI-NILAI MULTIKULTURAL DI SMAN 2 KEDIRI
}

\author{
Oleh: \\ Tri Wahyudi Ramdhan \\ STAI Darul Hikmah Bangkalan, Indonesia \\ wahyudi@darul-hikmah.com
}

\begin{abstract}
:
SMAN 2 Kediri is a school that was established in the era of independence which is a condition of historical value and is very adaptive and responsive to the dynamics of plural societies and the development of the education world in Kediri. And in maintaining the diversity that exists, the school has organized education in a democratic and fair and not dicriminative manner through a curriculum filled with multicultural values. To uncover the application of the curriculum with a load of multicultural values, a study was carried out on the concept of multicultural values that grew and developed in SMA 2 Kediri. This research is qualitative research with case study research and in data collection using in-depth interviews and observation techniques, as well as documentation. Then the data analysis technique uses interactive techniques from Milles and Huberman. The results showed that the concept of multicultural values implemented in SMA 2 Kediri is a concept of interrelated values and cannot stand alone and grow and develop simultaneously.
\end{abstract}

Keywords: Implementasi, Nilai, Multikultural, Pembelajaran

\section{A. Pendahuluan}

Kajian tentang pendidikan multikultural terus berkembang dengan perspektif yang beragam. Dalam kajian ini, pendidikan agama Islam akan coba dilihat dalam perspektif multikultural. Sebagai sebuah fenomena pendidikan multikultural yang disandingkan dengan kurikulum pendidikan agama Islam, pada kajian kali ini akan mengambil lokasi di kota Kediri, tepatnya di sebuah sekolah menengah sekolah unggulan SMA 2 Kediri.

SMA 2 yang merupakan sekolah favorit lainnya di kota Kediri, didirikan pada tahun 1959. Sekolah ini memiliki jumlah siswa 981 dengan dominasi siswa muslim sebanyak 906 dan Protestan 52, sedangkan Katolik 21 dan terakhir Hindu 2 orang siswa. Selain siswa yang multireligius, siswa di sini juga layak pula di sebut sekolah multietnis 
karena terdapat siswa dari Papua dan Nusa Tenggara serta etnis China yang cukup banyak. ${ }^{1}$ Sehingga dalam menyikapi perbedaan ini SMA 2 telah menerapkan beberapa proram unggulan seperti Gerakan Literasi Sekolah (GLS), Penanaman Budi pekerti dan program sekolah Aman. Sehingga sekolah ini dipilih menjadi Sekolah Rujukan Nasional.

Dalam 7 program unggulan SMA 2, tiga diantaranya diperuntukkan untuk menanamkan nilai kebersaman di sana. Seperti dalam program pembelajaran penumbuhan budi pekerti, terdapat tim yang di bentuk dalam menimplementasikan program itu. Sedangkan program sekolah aman lebih menitik beratkan kepada sekolah yang aman bagi etnis minoritas dan sekolah yang ramah bagi semua.

Selain dengan program unggulannya, SMA 2 juga mengajarkan pendidikan Agama di luar jam pelajaran melalui kegitan ekstra keagamaan dan juga acara-acara keagamaan. Pembelajaran agama di SMA 2 selain pada mata pelajaran di kelas, juga dilakukan di unit layanan agama dengan tiga unit pelayanan, yaitu agama Islam, Protestan dan Katolik. Ekstra kulikuler keagaan di SMA 2 dirancang sedemikian rupa untuk menumbuhkan rasa toleansi antar umat beragama dan etnis di sana yang 1 majemuk. Bahkan, selain masjid sebagai tempat kerohajian siswa Agama Islam, pihak sekolah menyiapkan ruangan yang disetting menyerupai gereja yang menjadibtempat kerohaian kristen yang terletak di sebelah UKS dan tempat kerohanian Katholik yang terletak di gedung depan. ${ }^{2}$

Selanjutnya, pihak sekolah melibatkan siswa yang beragama lain dalam perayaan Hari Besar Keagamaan. Seperti pada saat acara Paskah dan Natal siswa Kristen dan Katolik berkolaborasi merayakannya di sana. Dan juga, ketua TMA (Takmir Masjid al-Anwar) juga di berikan waktu untuk memberikan sambutan. Selain itu, dalam acara roadtread (acara kerohanian yang diadakan UKAT dan UKRIS) siswa Kristen yang di adakan di Gereja Poh Sarang, kepala sekolah secara tidak terduga hadir memantau dan memberikan sambutan di sana. ${ }^{3}$

Implementasi nilai-nilai multikultural yang terdapat dalam keseharian SMA 2 Kediri menjadi alasan pemilihan lokasi studi kali ini. Dan dari latar belakang itulah, penulis ingin mengadakan penelitian di Kota Kediri tentang Pendidikan Multikultural dengan fokus kajian implementasi nilai-nilai multikultural. Fokus kajian ini dimaksudkan dapat

\footnotetext{
1 Observasi pada 271218.

2 Wawancara dengan. WKK.P. pada 070319 dan observasi pada 291216

3 Wawancara dengan.KS.TH pada 240319 dan wawancara dengan. S.NN pada 240319 serta wawancara dengan.GA.HR pada 050419.

154 JURNAL LISAN AL-HAL
} 
memberikan informasi mengenai pentingnya pendidikan multikultural yang berimplikasi bagi penanaman nilai-nilai multikultural di lingkungan sekolah.

\section{B. Metode Penelitian}

Penelitian ini merupakan jenis penelitian lapangan studi kasus dengan pendekatan deskriptif kualitatif. Penelitian ini berupaya untuk melihat secara mendalam serta menjelaskan bagaimana nilai-nilai pendidikan Islam multikultural diimplementasikan di SMA 2 Kediri. Sumber data yang diperoleh adalah melalui pengamat atau yang diwawancarai yang termasuk kepala sekolah, guru, siswa, orang tua dan pihak terkait dalam penelitian di SMA 2 Kediri. Teknik pengumpulan data dilakukan dengan observasi, wawancara mendalam, dan dokumentasi. Analisis data dilakukan dalam tiga tahap, yaitu reduksi data, penyajian data, dan penarikan kesimpulan / verifikasi.

\section{Temuan penelitian}

Nilai multikultural yang tumbuh dan berkembang di SMA 2 kediri merupakan satu kesatuan atau merupaan nilai yang saling melengkapi satu dengan yang lainnya. Sebagai contoh, ketika mengembangkan nilai multikultural terkait dengan kesetaraan, maka di dalamnya terdapat nilai multikultural lainnya seperti: keadilan, demokrasi. Begitu juga bila dikembangkan nilai kasih sayang, maka akan muncul juga nilai empati, solidaritas.

Selain berketerkaitan, nilai multikultural juga saling mempengarui nilai yang lain. Misalkan nilai toleransi akan muncul karena keberagaman etnis, agama, ras, strata sosial. Dari nilai ini akan tumbuh nilai lain yaitu kasih sayang, empati dan solidaritas. Dari ketiga nilai ini akan tumbuh nilai yang lagi kesetaraan, keadilan serta ketulusan, dan seterusnya sebagaimana gambar di bawah ini. 


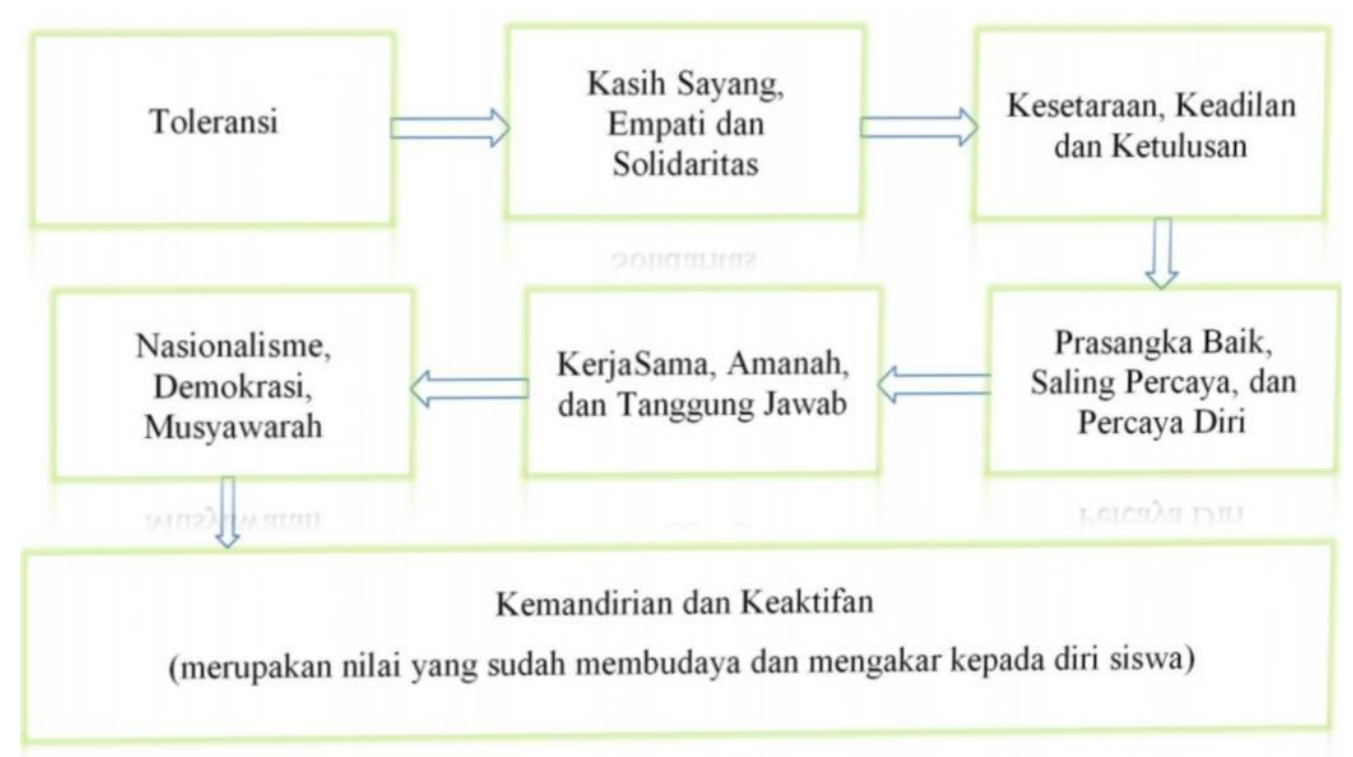

Gambar 1

Model Nilai multikultural yang berkembang di SMA 2

Setelah mengidentifikasi sejumlah nilai multikultural yang bersumber dari observasi, wawancara dan dokumentasi, temuan nilai tersajikan sebagai berikut:

\section{Toleransi}

Keberagaman warga sekolah di SMA 2 yang terdiri dari berbagaimacam perbedaan stata sosial, agama terutama perbedaan ras dan suku bangsa, dimana warga tionghoa di Kediri akan memilih SMA 2 sebagai prioritas utama mereka. Maka untuk mendukung terciptanya suasana kehidupan yang harmonis diperlukan adanya upaya keras dan kesadaran semua pihak untuk mengembangkan nilai toleransi. Upaya penanaman nilai toleransi di lingkungan sekolah tersebut dapat dilakukan melalui bentuk tindakan dan fasilitas di sana seperti halnya adanya tempat kerohanian untuk agama Islam, Kristen dan Katholik. Sikap toleransi juga di temui dalam tata tertib guru yang mana pada point 15 guru diwajibkan bertindak obyektif dan tidak diskriminatif.

Dari nilai toleransi ini akan memunculkan nilai yang lain, yaitu nilai kasih sayang, empati dan solidaritas. Karena siswa yang telah menyerap nilai toleransi yang telah diprogramkan oleh sekolah, secara tidak

156 JURNAL LISAN AL-HAL 
langsung dia akan memupunyai rasa kasih sayang, empati dan solidaritas kepada sesama

Kasih sayang, empati, solidaritas

Dalam menumbuhkembangkan ketiga nilai ini, sekolah membuat program khusus melalui santunan meringankan beban warga sekokah yang keluarganya meninggal dunia. Program ini dikoordinir oleh OSIS unit bakti sosial. Selain program sponanitas di atas, ada juga program buka puasa bersama anak panti asuhan yang dilakukan pada bulan ramdhan. Bahkan orang tua siswa juga memberikan rasa kasih sayang, solidaritas dan empati kepada warga sekolah yang lain. Saking perhatiannya mereka terhadap sekolah, mereka membentuk suatu paguyupan antar orang tua murid. Tujuan dari paguyupan ini adalah memberikan segala kebutuhan sekolah seperti pemberian fasilitan jaminan kesehatan kepada warga sekolah yang kurang mampu dan kepada semua guru yang sedang berobat atau menjalani rawat inap.

Dari ketiga nilai ini, hemat peneliti memunculkan nilai lain yang berhubungan dan bersinggungan seperti kesetaraan, keadilan dan ketulusan. Karena dari kasih sayang yang di eksternalisasikan satu individu ke individu yang lain mengakibatkan muncul rasa empati dan solidaritas. Selanjutnya rasa solidaritas dan empati yang mana warga SMA 2 merasakan apa yang orang lain rasakan menumbuhkan nilai kesetarann dan ketulusan. Dari sini muncul lagi nilai keadilan.

\section{Kesetaraan, Keadilan, Ketulusan}

Nilai ini banyak sekali terlihat dimana pelayanan kegitan keagamaan juga diberikan porsi yang sama. Semisal dalam siswa muslim terdapat pondok romadhon, siswa non muslim juga diberi wadah kegiatan romadhon dalam acara Retreat untuk siswa Kristen dan Wisata Rohani untuk siswa Katholik. Bahkan sikap keadilan dan kesetaran dan ketulusan juga terlihat dalam stuktur organisasi guru di sana dimana tidak hanya guru yang muslim saja yang dapat menjabat wakil kepala sekolah, bahkan guru yang non muslim kerap menjadi wakil kepala sekolah di sana. Selain itu dalam pengurus organisasi baik itu OSIS, MPK ataupun kegiatan kesiswaan yang lain di sana tidak pernah ada diskriminasi dan ketidakadilan.

Kesetaraan yang tumbuh dan berkembang di SMA 2 kiranya menurut peneliti memunculkan nilai keadilan yang mana dari nilai keadilan ini memunculkan nilai ketulusan sehingga warga di sana tidak ada rasa curiga dan prasangka buruk kepada warga yang lain. Hal ini juga dibuktikan dengan beberapa keterangan di atas dimana pwmbagian tugas 
tidak memangdang agama, gender dan ras. Semua mendapat porsi yang sama.

\section{Prasangka baik, saling percaya, percaya diri}

Nilai saling percaya dan prasangka baik ini dapat dibuktikan dengan dianggapnya peneliti sebagai salah satu warga sekolah yang notabene peneliti adalah orang luar yang baru mengenal SMA 2. Selama peneliti di sana, peneliti diberikan ruangan khusus dan juga setiap ada rapat dan kegiatan peneliti diundang untuk ikut andil didalamnya. Peneliti juga diarahkan dan diperkenalkan tentang SMA 2 mulai dari keberagaman di sana, tradisi, kebiasaan yang dilakukan dan juga peneliti diberikan pendamping khusus dalam menyelesaikan tugas sehingga percaya diri peneliti tumbuh serta peneliti merasa menjadi bagian dari warga SMA 2 Selain itu, masyarakat sekitar juga mempunyai sikap percaya dan prasangka baik kepada anak SMADA. Bahkan saking percayanya mereka kepada anak SMA 2 sehingga hanya menerima anak khos dari SMA 2.

Peneliti dapat menyimpulkan bahwa nilai prasangka baik dapat menumbuhkan nilai saling percaya yang mana nilai ini bisa berkembang tidak hanya di lingkungan sekolah, bahkan orang tua dan lingkungan sekitar sekolah juga mempunyai sikap percaya kepada anak SMA 2. Dan implikasinya mereka menjadi percaya diri karena anak mereka sekolah di sini dan mempunyai anak khos berasal dari SMADA. Dari ketiga nilai itu, akan menarik nilai multikultural yang lain yaitu kerjasama, amanah dan tanggung jawab. Karena prasangka baik dan saling percaya antar warga sekolah dapat membuat kerjasama antar stekholder berjalan baik sehingga mereka bertanggung jawab atas apa yang mereka amanatkan.

\section{Kerjasama, Amanah, tanggung jawab}

Nilai kerjasama ini tumbuh dalam banyakknya program yang ada di SMA 2, baik program yang dilakukan oleh siswa maupun guru di sana. Sebagai contoh dalam pelaksanaan SID (Smada Islamic Day), yang mana tidak hanya kerjasama antar siswa muslim, tetapi juga siswa non muslim. Hal ini dikarenakan siswa non muslim juga ikut menjadi panitia pelaksanaan event ini. Padahal dari nama saja sudah dapat diketahui bahwa event ini merupakan event untuk memeriahkan hari besar Islam. Kerjasama juga dilakukan anatar guru sekolah dalam wadah MGMPS antar mata pelajaran dimana Guru biasa membagi tugas dan tanggung jawab dalam membuat perangkat pembelajaran. Mereka umumnya diketua oleh dalah satu guru senior dalam MGMPS Mata pelajaran dan membagi tugas

$158 \mid$ JURNAL LISAN AL-HAL 
untuk membuat RPP dan UKBM per kelas

Dan dari ketiga nilai ini akan melahirkan nilai yang lain, yaitu nilai nasionalisme, demokrasi dan musyawarah. Mengapa demikina, karena kerjasama yang baik itu ada sebab koordinasi antaar individu yang bagus. Hal ini pastinya mereka sering mengadakat rapat untuk bermusyawarah dalam merumuskan sesuatu, selalu mengedepankan demokrasi dalam merencanakan program sekolah.

\section{Nasionalisme, Demokrasi, Musyawarah}

Nilai Nasionalisme, demokrasi dan musyawarah merupakan ketiga nilai yang ada karena kehidupan berbangsa dan bernegara dan tentu saja SMA 2 kediri juga metumbuhkembangkan ketiga nilai ini dengan diadaknnya upacara bendera pada setiap hari senin. Selain upacara bendera, juga terdapat program bela negara dan pembiasaan siswa di pagi hari untuk menyanyikan lagu kebangsaan Indonesia Raya serta hormat kepada bendera sebelum pelajaran dimula. Proses demokrasi dan musyawarah juga terlihat dalam penyusunan Visi Misi sekolah yang melibatkan OSIS sebagai perwakilan siswa, Komite Sebagai Perwakilan Orang tua, RT, RW dan Kades sebagai perwakilan mayarakat sekitar, juga ada tokoh mayarakat juga unsur TNI dan Polri. Jadi penyusunan VISI, MISI dilakukan dan dievaluasi setiap tahun secara musyawarah besar bersama agar SMA 2 dapt berjalan dengan baik tidak lekang oleh waktu.

Dari proses demokrasi dan musyawarah bersama yang mana proses ini melibatkan siswa dalam menentukan arah kemajuan SMA sehingga para siswa mempunyai jiwa cinta almamater, jiwa Nasionalisme yang tinggi. Selain itu siswa juga percaya diri dan mempunyai sifat mandiri dan aktif . kedua nilai mandiri dan aktif ini merupakan nilai tradisi yang sudah mengakar kuat di sana dan akan dibahas setelah ini.

\section{Kemandirian dan keaktifan}

Nilai ini merupakan nilai tradisi dan budaya yang selalu ditumbuhkembangkan oleh siswa SMA 2 Kediri dari generasi ke generasi. Nilai kemandirian dan keaktifan seakan menjadi pembeda antara siswa SMA 2 dengan siswa SMA yang lain di kediri yang telah mengakar kuat. Karena nilai ini yang selama peneliti amati di sana, terlhat jelas dan menjadi ciri khas tersendiri serta menjadikan peneliti tertarik berbetah mengamati semua kegiatan di sana baik dalam proses pembelajaran maupun dalam kegiatan ekstrakurikuler.

Siswa SMA 2 kediri selalu berinisitaf melakukan semua kegiatan kesiswaan secara mandiri. Semua kegiatan kesiswaan mulai dari proses 
perencaan sampai proses pelaporan kegiatan dilakukan oleh siswa tanpa ada guru yang membantu. Selama peneliti mengamati di sana, guru tidak pernah menginstruksikan adanya sebuah kegiatan, menyususun jalannya acara kegiatan, mencarikan dana dan sponsor kegiatan dan sebagainya. Semua itu murni dilakukan oleh siswa.

\section{Pembahasan}

Nilai diartikan oleh beberapa ahli dengan berbagai bahasa yang berbeda. Adanya perbedaan dari pengertian tentang nilai ini dapat dimaklumi karena nilai tersebut berhubungnan erat trehadap definisi dan aktivitas manusia yang komplek. Bahkan, Kosttaf memandang nilai berupa kualitas empiris tak berdefinis, tapi dapat dipahami dan dialami secara langsung. Nilai bersifat abstrak dibalik fakta dan dapat memunculkan tindakan yang terdapat dalam moral seseorang, dan berkembang lebih kompleks ${ }^{4}$ Tetapi ada beberapa hal dapat dipahami tentang nilai, bahwa nilai dapat diartikan sebagai keyakinan yang membuat seseorang bertindak atas dasar pilihannya. Nilai bisa berupa norma, peraturan, etika, adat kebiasaan, undang-undang, aturan agama dan rujukan lainnya yang berharga bagi seseorang. ${ }^{5}$

Sedangkan nilai multikultural yang ditumbuhkembangkan SMA 2 Kediri tidak jauh berbeda dengan nilai multikultural yang ditawarkan oleh Asosiasi Guru Pendidikan Agama Islam Indonesia(AGPAII) melalui workshop pendidikan multikultural berupa nilai toleransi, kesetaraan, keadilan, ketulusan, kasih sayang, empati, solidaritas, kerjasama, amanah, tanggung jawab, prasangka baik, saling percaya, percaya diri, nasionalisme, demokrasi, musyawarah. ${ }^{6}$

Nilai-nilai multikultural yang dikembangkan kedua sekolah tersebut mengembangkan teori Abdullah Aly tentang nilai-nilai multikultural yang membagi menjadi tiga rumpun nilai, yaitu : 1) berprinsip pada demokrasi, kesetaraan dan keadilan; 2) berorientasi pada Kemanusiaan, kebersamaan dan kedamaian; 3) mengembangkan sikap mengakui, menerima dan menghargai keberagaman. ${ }^{7}$ Nilai-nilai

4 Thoha Chatib, Kapita Selekta Pendidikan Islam, (Yogyakarta: Pustaka Pelajar, 1996), 61. 9.

${ }^{5}$ Mulyana, Kurikulum berbasis Kompetensi, (Bandung: Remaja Rosda Karya, 2004),

${ }^{6}$ Tim Direktorat Pendidikan Madrasah Kementrian Agama, Wawasan Pendidikan Karakter, (Jakarta: Direktorat Pendidikan Madrasah Kementrian Agama, 2010), 124-127.

${ }^{7}$ Abdullah Aly, Pendidikan Islam Multikultural di Pondok Pesantren, elaah terhadap Kurikulum Pondok Pesantren Modern Islam Assalam Surakart, (Yogyakarta: Pustaka $160 \mid$ JURNAL LISAN AL-HAL 
multikultural tersebut merupakan satu rumpun nilai yang saling berkaitan dan dapat menumbuhkan nilai multikultural yang lain.

Dari hasil temuan di tempat penelitian, nilai multikultural tumbuh dan berkembang secara bersamaam. Hal ini terlihat dari satu kegitan semisal santunan meringankan beban warga sekokah yang tertipa musibah, yang mana dari satu kegiatan ini akan nampak nilai kasih sayang, empati, solidaritas. Lebih lanjut dari program santunan ini, para warga sekolah tidak membedakan antara murid satu dengan yang lain baik berasal dari etnis, agama serta strata sosial yang berlaian. Mereka memberikan santunan secara tulus tanpa meihat latar belakang murid dan diberikan secara adil dan sama.

Dari sini, ketiga nilai kasih sayang, empati, solidaritas, hemat peneliti akan memunculkan nilai lain yang berhubungan dan bersinggungan seperti kesetaraan, keadilan dan ketulusan. Karena kasih sayang yang diberikan secara adil dan sama dari individu ke individu yang lain mengakibatkan muncul nilai kesetarann dan ketulusan serta nilai keadilan. Untuk itu akan dibahas satu persatu rumpun nilai multilkultural yang ditemukan baik dalam material kultur dan aktivitas kultur (behavioral culture) di bawah ini yang dimulai dengan nilai toleransi.

1. Toleransi

Dalam Bahasa Arab toleransi lebih dikenal dengan sitilah alTasamuh yang mempunyai arti saling memudahkan. Istilah toleransi sendiri diserap dari Bahasa Inggris tolerance yang mempuyai makna sikap saling mengakui dan menghormati keyakinan orang lain tanpa memerlukan persetujuan.8 Sikap ini dapat dikembangkan melalui sikap mengakui, menghargai dan menerima perbedaan yang akhirnya akan membentuk toleransi.

Sejalan dengan hal tersebut, menurut Donna M. Gollnick, sikap menerima, mengakui dan menghargai perbedaan yang membentuk toleransi sangat diperlukan, karena sikap ini merupakan mozaik dalam suatu masyarakat yang didalamnya terdapat semua kebudayaan dari masyarakat kecil (microculture) yang merupakan perwujudan masyarakat yang besar (macroculture). ${ }^{9}$

Pelajar), 2011. 124

${ }^{8}$ David. G. Gularnic, Webster's Word Dictionary of American Languenge, dalam Said Agil Husain al-Munawar, Fikih Hubungan antar Agama,(Jakarta: Ciputat Press, 2005), 13.

${ }^{9}$ Abdullah Aly, Pendidikan Islam Multikultural di Pondok Pesantren, elaah terhadap Kurikulum Pondok Pesantren Modern Islam Assalam Surakart (Yogyakarta: Pustaka Pelajar, 2011), 119. 
Amir Hussain menambahkan bahhwa keberagaman merupakan suatu fitrah dan sunatullah yang mengandung pentingnya berdialog dan bersikap toleransi sebagaimana ketika Rasul SAW memperkenalkan Islam kepada masyarakat Makkah dan Madinah. Senada dengan ini, Abu khalid al-Fadl memberikan gambaran mengenai sikap toleransi Rasul SAW dalam menghargai dan mengakui serta menerima perbedaan. Seperti sikap toleran Rasul kepada semua warga Madiah baik muslim maupun non muslim. ${ }^{10}$

Salah satu contoh sikap toleransi Nabi SAW adalah pada saat para kaum Nasrani Bani Najran tiba di Madinah, mereka sempat meminta izin kepada Nabi SAW untuk melakukan Misa di Masjid Nabawi. Hal tersebut sontak menimbulkan kecemburuan dari para sahabat yang menghendaki Masjid Nabawi hanya boleh dimasuki oleh kaum Muslimin. Tetapi Nabi SAW justru mengberikan izin kepada para kaum Nasrani Bani Najran untuk melakukan kegiatan peribadatan mereka di sana. Kiranya uraian di atas, jelas melegitimasi nilai toleransi Rasul SAW dalam menghargai dan mengakui serta menerima perbedaan.

Senada dengan nilai toleransi yang diajarkan Nabi SAW yang memfasilitasi para Nasrani Bani Najran melakukan peribadatan mereka, peneliti menjumpai adanya pemfasilitasan ruangan yang disetting seperti gereja untuk para siswa Kristen dan Katholik melakukan kegiatan kerohanian. Selain, itu mereka disediakan kesempatan dan pendanaan untuk merayakan paskah dan natal. Bahkan pada saat acara Smada Islamic Day, siswa non muslim juga turut andil menjadi panitia perayaan ini.

Bahkan ketika perayaan paskah dan natal, pengurus OSIS pun hadir memberikan sambutan di sana. Tidak hanya itu, salah satu guru agama Islam pun juga hadir memberikan sambutan perayaan natal. Hal ini memang bertujuan supaya tidak ada istilah agama mayoritas dan minoritas. Semua agama dapat berbaur dan saling menghormati. Sehingga menjadikan semua kelompok dapat membaur tanpa membedakan status keagamaan mereka.

Sekolah juga mensiasati agar siswa mayoritas dapat membaur dan tidak memandang sentimen keagamaan dengan tidak mengelompokkan mereka dalam pembagian kelas. Dengar artian, mereka yang minoritas di sebar di seluruh kelas agar siswa terbiasan menghadapi perbedaan. Bahkan ada salah satu kelas yang sengaja disetting majemuk dimana dalam satu kelas ini terdapat siswa dengan agama yang bermacam-macam seperti Islam, Protestan Katholik, Hindu dan Budha.

10 Ibid, 121-122.

$162 \mid$ JURNAL LISAN AL-HAL 
Peneliti dapat menyimpulkan bahwa nilai toleransi ini berhubungan nilai yang lain, yaitu nilai kasih sayang, empati dan solidaritas. Karena siswa yang telah menyerap nilai toleransi yang telah diprogramkan oleh sekolah, secara tidak langsung dia akan memupunyai rasa kasih sayang, empati dan solidaritas kepada sesama, sehingga ketiga nilai tersebut muncul dan berkembang.

2. Kasih Sayang, Empati dan Solidaritas

Dalam menanggapi ketiga nilai kasih sayang, empati dan solidaritas, terdapat sebuah hadis yang diriwayatkan oleh Imam Bukhari yang menerangkan "Orang mukmin yang satu dengan yang lain bagai satu bangunan yang bagian-bagiannya saling mengokohkan." Secara tidak langsung Rasul SAW mengajarkan kepada kita untuk bisa merasakan apa yang dirasakan orang mukmin yang lain.

Bahkan bukan hanya sesama muslim yang mana kita harus menebar rasa kasih sayang, empati dan solidaritas, tetapi kita juga harus menyebarkan rasa cinta kasih sayang di dunia baik kepada manusia, hewan, tumbuhan, dan ciptaan lainya. Hal ini sebagaimana komentar anNawawi al-Bantani dalam sebuah hadits "orang-orang yang penyayang akan disayang oleh dzat yang penyayang. Maka sayangilah yang ada di bumi, niscaya yang di langit akan sayang kepada kalian."11

Berdasarkan paparan di atas, pengejawantahan nilai kasih sayang, empati dan solidaritas yang peneliti temui di lapangan sangatlah banyak. Seperti program santunan meringankan beban warga sekokah yang mengalami musibah. Program ini dikoordinir oleh OSIS unit bakti sosial. Dalam penerapannya, siswa yang mendapatkan kabar tentang warga atau orang tua temannya yang tertimpa musibah langsung berkoordinir dengan unit bakti sosial.

Selain program sponanitas di atas, ada juga program buka puasa bersama anak panti asuhan yang dilakukan pada bulan ramdhan serta santunan anak yatim di panti asuhan menjelas UN. Ada juga kegiatan bantuan kemanausisan bagi korban bencana alam di pacitan serta pembagian nasi bungkus kepada masyarakat sekitar yang kurang mampu. Semua kegiatan di atas diadakan dalam rangka kepedulian sesama dan menumbuhkan rasa kasih sayang.

Dari nilai kasih sayang, empati dan solidaritas -hemat penelitiakan memunculkan nilai lain yang berhubungan dan bersinggungan seperti kesetaraan, keadilan dan ketulusan. Karena dari kasih sayang yang

11 Abdul Wahid Hasan, "sebuah pengantar" dalam Machasin, ,Islam Dinamis, Islam Harmonis, (Yogyakarta: LKIS, 2012), Vii. 
di eksternalisasikan satu individu ke individu yang lain mengakibatkan muncul rasa empati dan solidaritas. Selanjutnya dari rasa solidaritas dan empati yang mana warga SMA 2 merasakan apa yang orang lain rasakan menumbuhkan nilai kesetarann dan ketulusan. Dari sini muncul lagi nilai keadilan.

3. Kesetaraan, Keadilan, dan Ketulusan

Ketiga nilai ini dilegitimasi oleh al-Qur'an antara lain, ditemukan keberadaannya dalam al-Baqarah [2]: 256; al-Kafirun [109]: 1-6; alHujurat[49]: 9; an-Nisa'[4]: 135; al-Maidah [5]: 8; al-A'rof [7]: 29-30; alAhzab [33]: 35; al-Hujarat [49]: 9; ar-Ra'd [13]: 10 dan lain sebagainya. Selain itu, Rasulullah SAW dalam mengelola keragaman kelompok di Madinah -pada saat pertama kali memasuki kota Madinah- membuat perjanjian tertulis yang populer dengan sebutan Piagam Madinah. Yang mana dalam piagam tersebut, seluruh penduduk Madinah memperoleh status yang sama dan persamaan dalam kehidupan. Hal ini terkandung dalam Piagam Madinah pada pasal 16 dan $46^{12}$

Prinsip ini memberikan isyarat bahwa manusia secara fitrah kejadiaanya adalah makhluk yang berbeda, namun Islam tidak mengajarkan doktrin rasisme, -yang menempatkan suatu kelompok secara superior atas kelompok- sekaligus juga menjadi makhluk yang setara dalam fungsi sosialnya. Berkenaan dengan konsep kesetaraan adalah merupakan kesejajaran harkat dan martabat, serta meratanya keadilan tanpa ada sekat perbedaan perbedaan warna kulit, kedudukan sosial maupun tingkat ekonomi.

Upaya peneliti dalam mengungkap ketiga nilai di atas saat memasuki komunitas masyarakat plural menemukan akan pentingnya ketiga nilai ini baik dalam tatanan sosial budaya, agama, ras, dan gender. Selama peneliti mengamati dan mewawancarai seluruh stekholder di sana, penerapan nilai ini terlihat jelas dalam palayanan keroharian, kegiatan pembelajaran dan ektrakurikuler yang sama dan tidak membedakan satu dengan yang lain. Seperti disaat siswa Muslim terdapat masjid untuk kegiatan kerohaniaanya, untuk siswa Protestan dan Katholik juga

12 "Dan bahwa orang Yahudi yang mengikuti kami akan memperoleh hak perlindungan dan hak persamaan tanpa ada penganiayaan dan tidak ada orang yang membantu musuh mereka" (pasal 16).

"Dan bahwa Yahudi al-Aus, sekutu mereka dan diri (jiwa) mereka memperoleh hak seperti apa yang terdapat bagi pemilik shahifat ini serta memperoleh perlakuan yang baik dari pemilik shahifat ini" (pasal46).

$164 \mid$ JURNAL LISAN AL-HAL 
disediakan ruangan yang disetting menyerupai gereja sebagai tempat kerohaniaanya sebagaimana keterangan telah lalu.

HN -Guru non-muslim- mengungkapkan bahwa sikap keadilan dan kesetaran serta ketulusan dapat dibuktikan dengan tidak hanya guru yang muslim saja yang dapat menjabat wakil kepala sekolah, bahkan guru yang non muslim kerap menjadi wakil kepala sekolah.

Dan hubungan antar keduanya ya,ya nuwun sewu, professional tadi lho pak. Sekarang contoh aja ya, saya tu guru agama katolik di sekolah negeri. Saya tu bisa jadi waka lho pak. Jadi kemeren saya tu kan di wakasek sapras ajaran lalu. Sekolah lain itu ndak ada dan nggak pernah ada itu. Jadi langka gitu lho. Trus kemaren guru agama Kristen juga sempat juga jadi waka humas. Umumnya orang ya gak melihat tidak berdiri atas perbedaan. Agaknya yang berbau gitu-gitu no, di sini tu ndak, ndak laku gitu pak. Ndak respek

Kesetaraan memiliki nilai moral berupa konsep keadilan, keseimbangan, dan sikap ketulusan yang kesemuanya berkaitan dengan nilai-nilai multikultural. Kesetaraan yang tumbuh dan berkembang kiranya menurut peneliti memunculkan nilai keadilan yang mana dari nilai keadilan ini memunculkan nilai ketulusan sehingga warga di sana tidak ada rasa curiga dan prasangka buruk kepada warga yang lain. Hal ini juga dibuktikan dengan beberapa keterangan di atas dimana pembagian tugas tidak memangdang agama, gender dan ras. Sebab tanpa adanya kesadaran untuk berlaku adil dan tulus kepada pihak lain yang berbeda akan menimbulkan prasangka dan kecurigaan yang pada saatnya akan berubah menjadi konflik dan menyulutu api kekerasan. Sehingga selanjutnya, akan dibahas nilai prasangka baik, saling percaya dan percaya diri.

4. Prasangka Baik, Saling Percaya dan Percaya Diri

Dalam al-Qur'an surat al-Hujurat[49]: 12, kita diperintah untuk tidak berprasangka buruh dan percaya dan tidak mencaricari kesalahan orang lain. ${ }^{13}$ Hal ini pun juga dipertegas oleh Rasulullah SAW dalam hadits yang diriwayatkan oleh Bukhori Muslim.

"Berhati-hatilah kalian dari tindakan berprasangka buruk, karena prasangka buruk adalah sedusta-dusta ucapan. Janganlah kalian saling mencari berita kejelekan orang lain, saling memata-matai, saling mendengki, saling membelakangi, dan saling membenci. Jadilah kalian hamba-hamba Allah yang bersaudara"

13 "Hai orang-orang yang beriman, jauhilah kebanyakan berprasangka, karena sesungguhnya sebagian tindakan berprasangka adalah dosa dan janganlah kamu mencaricar kesalahan orang lain 
Dari ayat dan hadits di atas kita diperintah untuk saling percaya baik kepada orang lain terlebih kepada diri kita sendiri serta menjadi bersaudara dengan saling membantu satu sama lain. Dan pengalaman seperti itulah yang kiranya peneliti temukan di lokasi penelitian yang mana peneliti disambut dengan ramah bukan hanya sebagai orang luar, tetapi peneliti dianggap bagian dari SMA 2. Peneltiti juga dipersilahkan hadir disetiap rapat yang diadakan oleh dewan guru. Bahkan peneliti juga sempat menjadi pengawas UAS. Seakan tanpa ada rasa curiga, peneliti juga diharap dapat memberikan kontribusi dengan hadirnya peneliti di sana.

Peneliti dapat menyimpulkan bahwa nilai prasangka baik dapat menumbuhkan nilai saling percaya yang mana nilai ini bisa berkembang tidak hanya di lingkungan sekolah, bahkan orang tua dan lingkungan sekitar sekolah. Dari ketiga nilai itu, akan menarik nilai multikultural yang lain yaitu kerjasama, amanah dan tanggung jawab. Karena prasangka baik dan saling percaya antar warga sekolah dapat membuat kerjasama antar stekholder berjalan baik sehingga mereka bertanggung jawab atas apa yang mereka amanatkan.

5. Kerja Sama, Tanggung Jawab dan Amanah

Kerja sama dan tanggung antara sesama manusia mutlak dibutuhkan dalam mewujudkan cita-cita membangun masyarakat pluralis yang harmonis,. Dengan kerja sama dan tanggung jawab, perbedaan akan semakin menghilang sehingga akan saling bahu-membahu bersinergi mengejar harapan dan cita-cita bersama. Kenyataan ini menjadikan manusia untuk terus menjaga hubungan dengan pihak-pihak lain, kendati terdapat perbedaan-perbedaan di antara manusia yang tak bisa dihindarkan.

Kerja sama membutuhkan keterlibatan berbagai pihak dalam sebuah masyarakat atau komunitas. Sebuah masyarakat atau komunitas yang di dalamnya terdapat kerja sama merupakan ciri masyarakat yang sehat dalam suasana multikultural. Kerja sama dapat pula berarti saling bertanggung jawab atas dirinya dan tolong menolong. Untuk menunaikan manat yang diberikan berlandaskan kebaikan dan kemaslahatan. Pengakuan akan adanya nilai kerjasama dan saling bertanggung jawab atas amat tergambar dalam al-Maidah[5]: 2;14

Nilai kerjasama ini dalam banyak peneliti temukan di kedua loasi penelitian. Untuk program kesiswaan saja tercatat 42 kegiatan yang mana

14 dan bertolong menolonglah kamu dalam (mengerjakan) kebajikan dan takwa, dan jangan tolong menolong dalam berbuat dosa dan pelanggaran. Dan bertakwalah kamu kepada Allah, sesunnguhnya Allah amat berat siksanya

166 JURNAL LISAN AL-HAL 
bila tidak ada kerjasama dan tanggung jawab dari siswa, tidaklah mungkin semua program iu dapat berjalan selama satu tahun pelajaran. Salah satu contohnya adalah kegiatan Passis Smada (Pelepasan Siswa SMA 2) yang mana terjadi kerjasama dan pembagiann tugas serta tanggung jawab antar tingkatan kelas sebagaimana informan AHY ungkapkan .

Kerjasama ya ini misalkan kegiatan pasis itu perpisahan sela 10 bagiannya musik misalkan. Kelas 11 bagian managerial nya kegiatan. Kelas 12 pesertanya. Itu misalnya kerjasamanya. Ya sesuai kemampuannya to pak misalkan ekstranya smada ada musik itu banyak anak non muslim. band musik itu banyak non muslim. Cuman dirjen teerus yang nge-bandnya itu anak muslim dan penyanyi anak nonmuslim itu juga ada. Itu yang punyanya sampai waktu upacara 17 itu ada itu yang gita buana nusantara di jakarta itu pak. Itu tapi anak non muslim.

Bahkan dalam acara Smada Islamic Day, para siswa non-muslim juga membantu menjadi panitia dalam rangka mensukseskan jalannya acara tersebut. karena pada dasarnya manusia adalah diciptakan dari jiwa yang satu (nafs wahidah). Pelaksanaan nilai ini tidak memandang berbedaan tingkatan kelas, agama, status social dan lainnya sebagimana contoh di atas. Kenyataan ini menjadikan manusia untuk terus menjaga hubungan dengan pihak-pihak lain, kendati terdapat perbedaanperbedaan di antara manusia yang tak bisa dihindarkan. Sebagaimana ditandaskan dalam al-Nisa'[4]:1. ${ }^{15}$

Nilai kerjasama, amanat dan tanggung jawab begiu banyak nampak karena banyaknya program kegiatan baik itu dari siswa dan dari guru dan juga karena banyaknya stekholder di sana. Sehingga hal ini bila tidak ada koordinasi kerjasama yang baik, tidaklah mungkin menjadi sekolah yang besar dan maju. Dan dari ketiga nilai ini akan melahirkan nilai yang lain, yaitu nilai nasionalisme, demokrasi dan musyawarah. Mengapa demikina, karena kerjasama yang baik itu ada sebab koordinasi antar individu yang bagus. Hal ini pastinya mereka sering mengadakan rapat untuk bermusyawarah dalam merumuskan sesuatu, selalu mengedepankan demokrasi dalam merencanakan program sekolah.

6. Musyawarah, Demokradi dan Nasionalisme

Dalam kesempatan kali ini, penggalian data terkait dengan nilai musyawarah, demokrasi dan nasionalisme di lokasi pelitian adalah yang

${ }^{15}$ wahai sekalian manusia, bertakwalah kepada Tuhanmu yang telah menciptakan kamu dari diri yang satu, yang menciptakan darinya pasangannya; Allah memperkembangbiakkan dari keduanya laki-laki yang banyak dan perempuan. Dan bertakwalah kepada Allah yang dengan nama-Nya kamu saling meminta dan (pelihara pula) hubungan silaturrahim. Sessungguhnya Allah maha mengawasi kamu. 
ada karena kehidupan berbangsa dan bernegara. Selama peneliti mengamati dan mewawancarai di lapangan, banyak sekali programprogram yang mencerminkan penumbuhan nilai ini, semisal upacara bendera, program bela negara, menyanyikan lagu-lagu kebangsaan, Pasis, LKDS dan MOPDB dan lain sebagainya. Strategi tersebut dilakukan untuk menumbuhgembangkan nilai-nilai kebangsnnn dan cinta tanah air kepada siswa.

Dalam perspektif Islam, nilai demokrasi, musyawarah dan nasioalis yang merupakan karakteristik pendidikan multikultural, memiliki legitimasi dalam ayat-ayat al-Qur'an, utamanya al-Syura [42]: 38; alHadid[53]: 25; dan al-A'raf[7]: 181. Nilai ini memberikan landasan moral bahwa setiap orang diberi hak untuk menentukan pilihannya dan tidak mengajarkan pemaksaan bahkan mengajurkan bertukar fikiran bermusyawarah untuk keutuhan suatu bangsa.

Jika dilihat dari sisi sejarah peradaban Islam, prinsip dari nilai demokrasi, musyawarah dan nasionalisme telah dipraktikkan sendiri oleh Rasulullah SAW dalam mengelola kemajemukan bangsa di Madinah. Dalam hal ini, Rasulullah SAW membuat perjanjian tertulis yang sangat di kenal dalam lintasan sejarah Nabi SAW sebagai mitsaq madinah untuk mengelola keragaman kelompok dalam masyarakat Madinah.

Dalam beberapa kesempatan, sebagian kelompok dalam Islam berpendapat bahwa demokrasi bukanlah sebuah system yang dilahirkan dari rahim Islam, melainkan dari Barat, oleh karena itu demokrasi haruslah ditolak. Di sisi lain, mayoritas umat Islam menerima demokrasi sebagai sebuah system yang menghargai hak-hak individu yang tidak semestinya dibenturkan dengan ajaran Islam. Sehingga dalam konteks penelitian ini demokrasi merupakan nilai yang secara subtansi telah diajarkan oleh Nabi SAW.

7. Kemmandirian dan Keaktifan

Selain beberapa rumpun nilai yang telah dibahas di, atas, peneliti juga menemukan sebuah nilai baru yang merupakan inti dari kehidupan keseharian di salah satu lokasi penelitian (SMA 2) yaitu nilai kemandirian. Kemandirian berasal dari kata "independence yang menunjuk pada adanya kepercayaan akan kemampuan diri untuk menjadi lebih dewasa dalam menyelesaikan persoalan-persoalan dan dapat melakukan sendiri kegiatan-kegiatan serta menyelesaikan sendiri masalah-masalah yang dihadapi dengan penuh tanggung jawab. ${ }^{16}$ Sehingga dalam kemandirian

16 Parker. K Deborah, Membumikan Kemandirian dan Harga Diri Anak, (Jakarta: Prestasi Pustaka, 200), 226-227.

168 JURNAL LISAN AL-HAL 
meliputi tiga aspek yakni kemampuan menjadi dewasa dan pengambilan keputuasn serta bertanggung jawab atas timbulnya nilai-nilai yang abstrak (moral)

Nilai ini merupakan nilai tradisi dan budaya yang selalu ditumbuhkembangkan di SMA 2 Kediri dari generasi ke generasi. Seakan menjadi pembeda antara SMA 2 dengan siswa SMA yang lain di kediri, nilai ini yang selama peneliti amati di sana, terlhat jelas dan menjadi ciri khas tersendiri serta menjadikan peneliti tertarik berbetah mengamati semua kegiatan di sana baik dalam proses pembelajaran maupun dalam kegiatan ekstrakurikuler.

SMA 2 kediri selalu berinisitaf melakukan semua kegiatan kesiswaan secara mandiri. Semua kegiatan kesiswaan mulai dari proses perencaan sampai proses pelaporan kegiatan dilakukan oleh siswa tanpa ada guru yang membantu. Guru hanya sebagai pengawas dan pembingbing jalannya semua kegiatan. Seperti kegiatan dari unit takmir masjid alanwar yang mana pada tahun ini ada 32 kegiatan. Dalam penyusunannya, siswa SMA 2 mengumpulkan seluruh anggota TMA untuk melakukan rapat awal tahun. Dalam rapat ini selain menyusun acara kegiatan juga menyusun sumber dan besaran dana serta waktu pelaksanan acara kegiatan. Hal ini diamini oleh HM sebagai salah satu Pembina unit kesiswaan.

Cirinya anak-anak sini tu kalau terlalu di ini tu malah nggak, nggak jalan. Seperti contoh ya, mau retreat ke malang gitu ya. Gurune no malah bingung gitu ya. Kendaraane piye, biaya e piye? Kan gitu. Mereka malah langsung gitu pak. Mobil e saya, mobil e saya, biaya e saya. Malah jalan itu. Rebutan malah. Jadi lebih ini, di perdayakan malah berjalan.

Sikap seperti ini kiranya yang mana Rasululah SAW sangat mengajurkan mandiri. Hal ini diceritakan oleh Rasulullah SAW dalam sabdanya yang diceritakan dari Miqdam, bahwa beliau bersabda yang artinya, "Tiada sesuap pun makanan yang lebih baik dari makanan hasil jerih payahnya sendiri. Sungguh, Nabi Daud AS itu makan dari hasil keringatnya sendiri," HR Bukhari. Dampak kemandirian ini sangat luas dan kemandirian merupakan salah satu sifat para nabi.

Termotovasi dengan Hadits di atas, dalam setiap event acara yang diselenggarakan oleh SMA 2, para siswa tidak hanya mandiri dari segi event organizing, tetapi juga mandiri dalam pemenuhan biaya operasional. Hal ini tercermin dalam segala kegiatan kesiswaan dan perayaan-perayaan di sana. Seperti halnya acara pondok romadhon yang mana acara ini dikoordinasi oleh TMA mulai dari penyusunan materi dan pemateri, pengaturan jadwal, mencari biaya operasional dan mempersiapkan takjil 
dan buka puasa bagi peserta.

Nilai kemandirian juga terlihat saat siswa mewakili SMA 2 dalam kompetisi dan lomba di luar sekolah baik tingat regional, nasional dan internasional. Siswa mencari sendiri informasi terkait dengan lomba dan kompetensi di luar sekolah. Setelah itu mereka mengajukan diri mengikuti lomba tersebut ke guru mapel yang bersangkutan. Setelah mendapatkan persetujuan mereka menindaklanjutinya ke waka kesiswaan untuk diberikan surat rekomendasi dan surat dispensasi tidak ikut pelajaran. Dan biasanya dari surat rekomendasi tersebut dapat diajukan kebendaharan sekolah untuk pencairan dana terkait transport sekedarnya.

Nilai ini menurut pengamatan peneliti disatu sisi merupakan nilai yang menunjukkan identitas siswa di sana. Hal tersebut terjadi karena dengan nilai ini mereka dapat membaur dengan individu lain tanpa ada jarak. Selain itu, nilai kemandirian ini sulit untuk dilepaskan dari kebiasaan dan tradisi SMA 2 dari waktu ke waktu.

\section{E. Simpulan}

Pada bagian terakhir ini, peneliti coba menjawab fokus kajian ini terkait konsep implementasi nilai-nilai multikultural sebagai berikut. Sebagai lembaga pendidikan menengah atas yang memiliki sisi historis sangat panjang di Kediri, SMA 2 sangat adaptif serta responsif terhadap dinamika plural sosiety serta perkembangan dunia pendidikan di Kediri. Sehingga saat gejala radikalisme dan eksklusivisme Islam menjadi trending, kedua sekolah tersebut turut aktif berperan menyebarkan gagasan mengenai nilai multikultural.

Adapun penelusuran tentang konsep nilai multikultural yang tumbuh dan berkembang di kedua sekolah tersebut merupakan suatu konsep rumpun nilai yang saling berkaitan dan dapat menumbuhkan nilai multikultural yang lain. serta tumbuh berkembang secara bersamaan. Rumpun nilai multikultural trersebut adalah (1)kesetaraan, keadilan, ketulusan; (2) kasih sayang, empati, solidaritas; (3) kerjasama, amanah, tanggung jawab; (4) prasangka baik, saling percaya, percaya diri; (5) nasionalisme, demokrasi, musyawarah; (6) toleransi, serta terdapat temuan nilai baru (7) kekeluargaan; (8) kemandirian dan keaktifan. 


\section{DAFTAR PUSTAKA}

Wahid Hasan, Abdul. Sebuah Pengantar, dalam Machasin, Islam Dinamis, Islam Harmonis Yogyakarta: LKIS, 2012.

Abdullah Aly, Pendidikan Islam Multikultural di Pondok Pesantren, elaah terhadap Kurikulum Pondok Pesantren Modern Islam Assalam Surakart, Yogyakarta: Pustaka Pelajar, 2011.

David. G. Gularnic, Webster's Word Dictionary of American Languenge, dalam Said Agil Husain al-Munawar, Fikih Hubungan antar Agama, Jakarta: Ciputat Press, 2005.

Mulyana, Kurikulum berbasis Kompetensi, Bandung: Remaja Rosda Karya, 2004.

Parker. K Deborah, Membumikan Kemandirian dan Harga Diri Anak, Jakarta: Prestasi Pustaka, 2000.

Chatib, Thoha. Kapita Selekta Pendidikan Islam, Yogyakarta: Pustaka Pelajar, 1996.

Tim Direktorat Pendidikan Madrasah Kementrian Agama, Wawasan Pendidikan Karakter, Jakarta: Direktorat Pendidikan Madrasah Kementrian Agama, 2010. 
"Nilai-Nilai Multikultural"

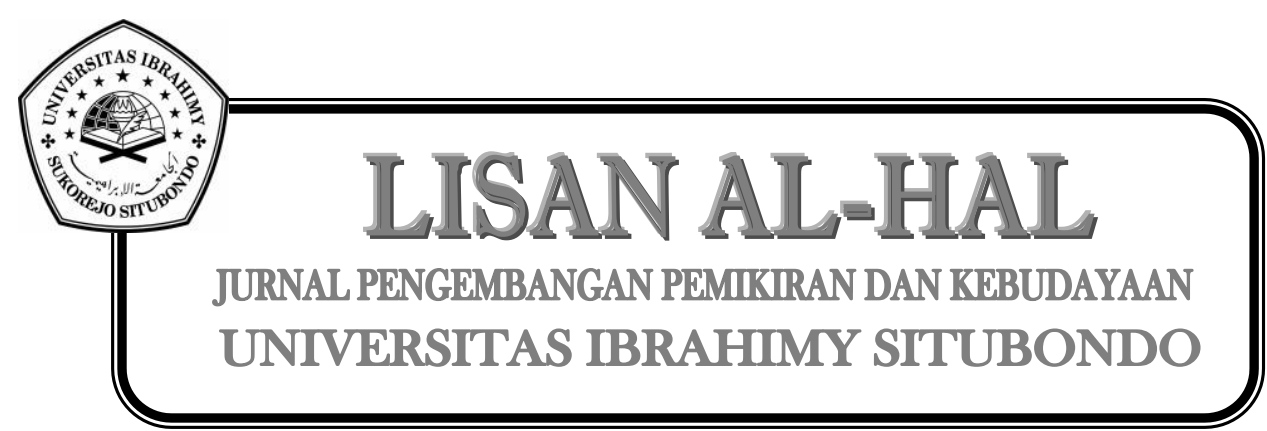

172 JURNAL LISAN AL-HAL 